\title{
Blood metabolic profile and acid-base status of Istrian goats - a critically endangered Croatian goat - in relation to age
}

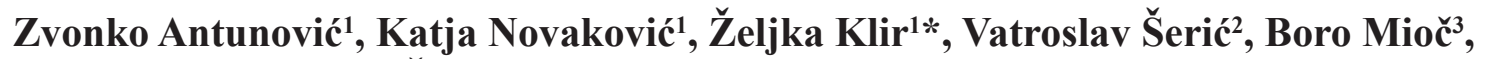 \\ Marcela Šperanda ${ }^{1}$, Mario Ronta ${ }^{1}$, and Josip Novoselec ${ }^{1}$ \\ ${ }^{1}$ Faculty of Agrobiotechnical Sciences Osijek, Josip Juraj Strossmayer University of Osijek, Osijek, Croatia \\ ${ }^{2}$ Department of Clinical Laboratory Diagnostics, University Hospital Osijek, Osijek, Croatia \\ ${ }^{3}$ Department of Animal Science and Technology, Faculty of Agriculture, University of Zagreb, Zagreb, Croatia
}

\begin{abstract}
ANTUNOVIĆ, Z., K. NOVAKOVIĆ, Ž. KLIR, V. ŠERIĆ, B. MIOČ, M. ŠPERANDA, M. RONTA, J. NOVOSELEC: Blood metabolic profile and acid-base status of Istrian goats - a critically endangered Croatian goat - in relation to age. Vet. arhiv 90, 27-38, 2020.
\end{abstract}

\section{ABSTRACT}

The aim of the present research was to determine the blood metabolic profile and acid-base status of Istrian goats in a Mediterranean production system. The research was carried out on 28, non-gravid Istrian goats divided into four groups: group I - $\leq 6$ month old kids; group II - $\leq 2$ year old goats; group 3 - from 2 to 5 year old goats; group IV - $>5$ year old goats. The goats were grazing on extensive Mediterranean pastures, but when in the stall, they were fed with hay and approximately $0.2 \mathrm{~kg}$ corn per day, as well as water and salt. Haematological parameters were determined in whole blood. The concentrations of biochemical parameters and enzyme activities were determined in the blood serum, while indicators of acid-base balance were determined in the blood plasma. The number of erythrocytes and lymphocytes decreased, while segmented neutrophils and eosinophils increased with age in the Istrian goats. Furthermore, concentrations of Fe, albumin/globulin ratio, cholesterol, triglycerides, LDL-cholesterol, VLDLcholesterol, inorganic phosphate- and the activity of alkaline phosphatase decreased significantly. An increase was determined in concentrations of urea, total proteins and globulins, as well as the activity of aspartate aminotransferase, weak anions and cations based on total protein calculations. The data obtained on the metabolic profile and acid-base status of Istrian goats are useful for understanding this breed's parameters, which will help in monitoring health and nutritional status, as well as for improving the management and conservation of this critically endangered breed.

Key words: metabolic profile; acid-base status; Mediterranean production system; Istrian goat

\section{Introduction}

According to FAO (2015), there are 4,772 local breeds of different mammals, and 576 breeds of goats in the world, while in Europe with the Caucasus, there are 2086 breeds, with 218 breeds of goats. Out of the total number of mammals in the world, $7 \%$ of them have already disappeared,

while $17 \%$ are critically endangered. Between 1999 and 2006, 690 breeds of mammals in the world disappeared, and 19 of them were breeds of goats. The Istrian goat is a critically endangered Croatian breed, developed and still reared in Istria. In the past, the number of reared goats was far higher than

\footnotetext{
*Corresponding author:

Željka Klir, PhD, Faculty of Agrobiotechnical Sciences Osijek, Josip Juraj Strossmayer University of Osijek, V. Preloga 1, 31000 Osijek, Croatia, Phone: +385 31554 906, E-mail: zklir@fazos.hr
} 
today. During the $20^{\text {th }}$ century, unfavourable social, economic and sociological events and adverse legal regulations for goat breeding led to the almost complete extinction of the goat population in Istria (IVANKOVIĆ et al., 2018). Thanks to the commitment and enthusiasm of individuals, a small number of Istrian goats have been preserved (MIOČ et al., 2013). In 2013, the Istrian goat was included in the List of Original and Protected Croatian breeds. Its adaptability to harsh conditions, modest requirements in terms of food and shelter, and high fertility were considered as the main advantages of the Istrian goat (IVANKOVIĆ et al., 2018). The Istrian goat is mostly reared for production of meat and milk. The area where the Istrian goat is reared is not entirely bounded by the state borders between Croatia and Slovenia, and Croatia and Italy. Nowadays, around 100 Istrian goats are being reared under selection control throughout the area of Istria. According to the data of the Croatian Agricultural Agency, the population of Istrian goats under selection control in Croatia is very small (38 heads: 33 goats, 1 female yearling and 4 bucks), which is only $0.51 \%$ of the total population of all registered goat breeds in Croatia (CAA, 2019). The Istrian goat has a white fleece, with greasy or cream shades. The average body weight of an adult goat is $55-80 \mathrm{~kg}$, average fertility is $150 \%$, while in lactation it produces $300-4001$ of milk. In the Mediterranean regions, the goat farming system is extensive, mainly based on natural feed resources. Whereas the "maquis" vegetation is widespread, these areas are characterised by summer drought (CABIDDU et al., 1999). An analysis of the genetic profile of the Istrian goat indicates a high level of preservation of genetic variability, which makes an important basis for its economic re-affirmation (IVANKOVIĆ et al., 2018). Better organization of farming, more comprehensive monitoring of production traits, as well as determination of the metabolic profile and acid-base status of the blood would lead to an increase in the Istrian goat population, and consequently to the sustainability of Istrian goat breeding (ANTUNOVIĆ et al., 2019).

The metabolic profile includes a set of specific blood-related indicators used for diagnosis, including haematological and biochemical parameters in the blood (VAN SAUN, 2000). It is even more important when goats are grazing on pasture, especially in Mediterranean areas with barren natural pasture, as it is then more difficult to monitor their consumption. In recent years, acid-base status has been determined extensively in order to define animals' health and production status. In addition to $\mathrm{pH}$, gas, electrolyte and excess base determination, different values of AG, SID, SIG, $z$-values, weak anions and cations (ATOT) and unmeasured anions (XA) are used (ANTUNOVIĆ et al., 2019; GÄRTNER et al., 2019). The results of numerous studies have shown that determination of the metabolic profile and acid-base status are important for monitoring metabolism and animal health (OTTER, 2013; MOHAMMED et al., 2016; ANTUNOVIĆ et al., 2013 and 2017a, b; REDLBERGER et al., 2017). The values of the blood metabolic profile parameters and acid-base status of goats are influenced by several factors, such as breed, age, physiological status; sex, nutrition or season (PICCIONE et al., 2010 and 2014; JONES, 2011; ARFUSO et al., 2016; ANTUNOVIĆ et al., 2017a; RADIN et al., 2017; RIBEIRO et al., 2018; GÄRTNER et al., 2019). Therefore, it is important to specify the individual values of metabolic profile and acid-base status for each goat breed, as well as to assess the impact of age. The aim of the present research was to determine the blood metabolic profile and acid-base status of Istrian goats in a Mediterranean production system.

\section{Materials and methods}

Animals and experimental design. Analysis of blood metabolic profile and acid-base status was performed on 28 non-gravid Istrian goats of different ages, in a traditional Mediterranean production system, during the summer season. The selected goats were healthy and in good physical condition. The goats were divided into four groups according to age: group I - $\leq 6$ month old kids; group II $-<2$ year old goats; group 3 - from 2 to 5 year old goats; group IV $->5$ year old goats. Each group contained 7 animals ( + ). The goats were grazing on extensive Mediterranean pastures and when in the stall they were fed hay (ad libitum) and approximately 0.2 $\mathrm{kg}$ of corn per day, as well as water and salt. The 
family goat farm was located in Galižana, about 9 $\mathrm{km}$ from Pula in Croatia.

Blood sample collection and parameters analysed. Aftermorning feeding, blood sampleswere collected from each goat's jugular vein $(10 \mathrm{~mL})$ into two sterile vacuum tubes Venoject ${ }^{\circledR}$ (Sterile Terumo Europe, Leuven, Belgium). One tube contained Li-heparin as an anticoagulant, and the other tube contained ethylenediamine tetra-acetic acid (EDTA). The following haematological parameters were determined: the number of leukocyte-WBC and erythrocytes-RBC, the content of haemoglobin, haematocrit, mean corpuscular volume-MCV, the average haemoglobin content in erythrocytes$\mathrm{MCH}$, and mean haemoglobin concentration in erythrocytes-MCHC. Haematological analysis was determined in whole blood and carried out on a three-part automatic differential haematology analyser Sysmex PocH-100iV (Sysmex Europe GmbH, Hamburg, Germany). The differential blood test was carried out using a microscope on prepared blood smears, coloured according to Pappenheim.

After this, blood samples were centrifuged at $1600 \mathrm{~g}$ for $10 \mathrm{~min}$ and the serum samples obtained were placed into an Olympus AU400 analyser (Olympus, Japan). The following biochemical parameters were determined in the serum: the concentrations of calcium, phosphorus-inorganic, sodium, potassium, magnesium, iron, chloride, urea, glucose, total proteins, albumin, cholesterol, HDL-cholesterol (high-density lipoprotein), LDLcholesterol (low-density lipoprotein), triglycerides, $\beta$-hydroxybutyrate (BHB) and non-esterified fatty acids (NEFA), as well as the activities of the enzymes: alanine aminotransferase (ALT), aspartate aminotransferase (AST), alkaline phosphatase (ALP), creatine kinase (CK) and $\gamma$-glutamyl transferase (GGT). Biochemical parameters were determined using Olympus System reagents (OSR) (Olympus Diagnostic GmbH, Lismeehan, Ireland). Globulin content was calculated as the difference between total protein and albumin. VLDL content was calculated as triglycerides divided by 5 (FRIEDEWALD et al., 1972). The activity of glutathione peroxidase (GPx) in the plasma was determined using a Ransel ${ }^{\circledR}$ kit (Randox, UK) on an automatic Olympus AU 400 (Olympus, Japan) analyser, at a wavelength of $240 \mathrm{~nm}$. The activity of total superoxide dismutase (SOD) in plasma was determined with a Ransod ${ }^{\circledR}$ kit (Randox, UK) on an automatic analyser (Olympus AU 400, Olympus, Japan) at a wavelength of $510 \mathrm{~nm}$.

Samples of plasma were obtained from sterile vacuum tubes containing Li-heparin and analysed by a RapidLab 348 automatic analyser (Siemens Healthcare Diagnostics Inc., USA), that works on the basis of ion-selective electrodes. The following parameters of acid-base status were determined: $\mathrm{pH}$, partial pressure of carbon dioxide $\left(\mathrm{pCO}_{2}\right)$, partial pressure of oxygen $\left(\mathrm{pO}_{2}\right)$, total pressure of carbon dioxide $\left(\mathrm{tCO}_{2}\right)$, actual base excess-Cbase(B), standard base excess-Cbase(Ecf) and electrolytes $\left(\mathrm{Na}^{+}, \mathrm{K}^{+}, \mathrm{Cl}^{-}\right.$and $\mathrm{HCO}_{3}^{-}$- bicarbonate). Strong ion difference (SID) was calculated according to STEWART (1983) following Eq. /1/, $z$ value was calculated according to WHITEHAIR et al. (1995) following Eq. /2/ and anion gap (AG) according to KANEKO et al. (2008) following Eq. /3/:

$$
\begin{array}{ll}
\mathrm{SID}=\left[\left(\mathrm{Na}^{+}+\mathrm{K}^{+}\right)-\mathrm{Cl}^{-}\right], & / 1 / \\
z \text { value }=\mathrm{SID} / \mathrm{Na}, & / 2 / \\
\mathrm{AG}=\left[\left(\mathrm{Na}^{+}+\mathrm{K}^{+}\right)-\left(\mathrm{Cl}^{-}+\mathrm{HCO}_{3}^{-}\right)\right] & / 3 /
\end{array}
$$

Weak anions and cations $\left(A T O T_{t p}\right.$ and $\left.A T O T_{a l b}\right)$ were calculated by multiplying the total protein (g/dL) or albumin by 2.9 (CONSTABLE, 1999; WALLER and LINDINGER, 2005). Strong ion gap (SIG) calculations were based on the serum concentrations of albumin $\left(A T O T_{\mathrm{alb}}, \mathrm{SIG}_{\mathrm{alb}}\right)$ and total proteins $\left(A T O T_{\mathrm{tp}}, \mathrm{SIG}_{\mathrm{tp}}\right)$ according to GÄRTNER et al. (2019) following Eq. /4/ and /5/. In these calculations $\mathrm{pKa}=7.06$ was used according to CONSTABLE (2002). Following Eq. (6) by GÄRTNER et al. (2019), unmeasured anions (XA) were calculated:

$$
\begin{aligned}
& \mathrm{SIG}_{\mathrm{alb}}=A T O T_{\mathrm{alb}} /\left(1+10^{(\mathrm{pKa}-\mathrm{pH})}\right)-\mathrm{AG}, \\
& \mathrm{SIG}_{\mathrm{tp}}=A T O T_{\mathrm{tp}} /\left(1+10^{(\mathrm{pKa}-\mathrm{pH})}\right)-\mathrm{AG}, \\
& \mathrm{XA}^{=} \mathrm{cNa}^{+}+\mathrm{cK}^{+}+\mathrm{cCa}^{2+}+\mathrm{cMg}^{2+}- \\
& \mathrm{cCl}^{-}-\mathrm{cHCO}_{3}-[0.141 \times \text { albumin } \times \\
& \quad(\mathrm{pH}-5.42)]-[0.04 \times \text { globulin } \times \\
& \quad(\mathrm{pH}-5.58)]-[\text { phosphate } \times 0.309 \times \\
& \quad(\mathrm{pH}-0.469)]
\end{aligned}
$$

Statistical analysis. The results of the goats' metabolic profile and parameters of acid-base 
status were obtained by the MEANS procedure, and expressed as the mean value and standard error of mean. Data were analysed by the general linear model (GLM) with age as the fixed effect. Mean values were compared using the Tukey test, and differences between the groups were declared significant at $\mathrm{P}<0.05$. All data were analysed with the statistical software SAS $9.4^{\circledR}$ (SAS Institute Inc., 2002-2012).

\section{Results}

From analysis of the data presented in Table 1 it is evident that the number of RBC and lymphocyte percentage in the blood of Istrian goats significantly decreases with age. In contrast, the percentage of segmented neutrophils and eosinophils in the blood of goats significantly increased with age. These changes were noticed when comparing goat kids ( $\leq 6$ months) with older goats. Additionally, no significant variations were recorded in the contents of WBC, HGB, HCT, MCH, MCV and MCHC in the blood of Istrian goat of different ages.

Concentrations of $\mathrm{Fe}, \mathrm{A} / \mathrm{G}$ ratio, cholesterol, triglycerides, LDL-cholesterol, VLDL-cholesterol and $\mathrm{P}$, as well as the activities of ALP, decreased significantly in the blood of goats with increasing age. Concentrations of urea, total proteins and globulins, as well as the activity of AST and content of $A T O T_{t \mathrm{p}}$ significantly increased in the blood of goats with increasing age (Tables 2, 3, 4 and 5). These changes were noticed when comparing goat kids ( $\leq 6$ months) with older goats.

In contrast, no significant differences were determined for blood concentrations of $\mathrm{Ca}, \mathrm{K}$, $\mathrm{Na}, \mathrm{Mg}$ and $\mathrm{Cl}$, or for concentrations of albumin, glucose, HDL-cholesterol, NEFA and BHB between goats of different ages. Likewise, no differences were determined in the activities of ALT, GGT, CK, GPx and SOD, or of most acid-base indicators in goats of different ages.

\section{Discussion}

In the present study, the number of $\mathrm{RBC}$ and lymphocytes in the blood of goats significantly decreased with age, although the content of segmented neutrophils and eosinophils significantly increased. The opposite trend was determined by ELITOK (2012) in the blood of Saanen goats

Table 1. Haematological parameters and distribution of leukocytes in the blood of Istrian goats of different ages

\begin{tabular}{|l|c|c|c|c|c|c|c|}
\hline Indicators & $\begin{array}{c}\text { Kids } \\
(\leq 6 \text { months })\end{array}$ & $\begin{array}{c}\text { Young goats } \\
(<2 \text { years })\end{array}$ & $\begin{array}{c}\text { Mature goats } \\
(2-5 \text { years })\end{array}$ & $\begin{array}{c}\text { Old goats } \\
(>5 \text { years })\end{array}$ & SEM & P-value & $\begin{array}{c}\text { Reference } \\
\text { values* }\end{array}$ \\
\hline WBC $\left(\times 10^{9} \mathrm{~L}\right)$ & 13.17 & 13.64 & 10.69 & 12.40 & 0.69 & 0.42 & $4.0-13.0$ \\
\hline RBC $\left(\times 10^{12} \mathrm{~L}\right)$ & $13.73^{\mathrm{a}}$ & 12.60 & $10.75^{\mathrm{b}}$ & 11.59 & 0.41 & 0.04 & $8.0-18.0$ \\
\hline $\mathrm{HGB}(\mathrm{g} / \mathrm{L})$ & 101.00 & 95.00 & 79.43 & 88.00 & 3.33 & 0.09 & $80.0-120.0$ \\
\hline $\mathrm{HCT}(\mathrm{L} / \mathrm{L})$ & 0.38 & 0.49 & 0.43 & 0.31 & 0.04 & 0.47 & $0.22-0.38$ \\
\hline $\mathrm{MCH}(\mathrm{pg})$ & 7.37 & 7.51 & 7.41 & 7.53 & 0.07 & 0.86 & $5.2-8.0$ \\
\hline $\mathrm{MCV}(\mathrm{fL})$ & 27.83 & 41.94 & 40.53 & 26.58 & 3.97 & 0.41 & $16.0-25.0$ \\
\hline MCHC $(\mathrm{g} / \mathrm{L})$ & 264.29 & 230.25 & 227.57 & 283.25 & 13.20 & 0.46 & $300-360$ \\
\hline Lymphocytes $(\%)$ & $72.86^{\mathrm{a}}$ & $63.00^{\mathrm{a}}$ & $48.29^{\mathrm{b}}$ & $46.25^{\mathrm{b}}$ & 2.83 & 0.0004 & $50-70$ \\
\hline Neutrophyls, seg. $(\%)$ & $25.71^{\mathrm{a}}$ & $29.00^{\mathrm{a}}$ & $46.43^{\mathrm{b}}$ & $45.25^{\mathrm{b}}$ & 2.55 & 0.0008 & $30-48$ \\
\hline Eosinophils $(\%)$ & $1.43^{\mathrm{a}}$ & $8.00^{\mathrm{b}}$ & 5.29 & $8.50^{\mathrm{b}}$ & 0.84 & 0.005 & $1-8$ \\
\hline
\end{tabular}

*Kramer (2000); a,b - values in rows with different letters differ significantly $(\mathrm{P}<0.05)$, SEM - standard error of mean; WBC leukocyte number, RBC - erythrocyte number, HGB - haemoglobin, HCT - haematocrit, MCH - average haemoglobin content in erythrocytes, MCV - mean corpuscular volume, MCHC - mean haemoglobin concentration in erythrocytes. 
Table 2. Blood mineral concentrations in Istrian goats of different ages

\begin{tabular}{|l|c|c|c|c|c|c|c|}
\hline Minerals & $\begin{array}{c}\text { Kids } \\
(\leq 6 \text { months })\end{array}$ & $\begin{array}{c}\text { Young goats } \\
(<2 \text { years })\end{array}$ & $\begin{array}{c}\text { Mature goats } \\
(2-5 \text { years })\end{array}$ & $\begin{array}{c}\text { Old goats } \\
(>5 \text { years })\end{array}$ & SEM & P-value & $\begin{array}{c}\text { Reference } \\
\text { values* }\end{array}$ \\
\hline $\mathrm{Ca}(\mathrm{mmol} / \mathrm{L})$ & 2.24 & 2.20 & 2.20 & 1.98 & 0.04 & 0.22 & $2.3-2.9$ \\
\hline $\mathrm{P}(\mathrm{mmol} / \mathrm{L})$ & $2.91^{\mathrm{a}}$ & $1.96^{\mathrm{b}}$ & $1.82^{\mathrm{b}}$ & $1.92^{\mathrm{b}}$ & 0.13 & 0.002 & $1.0-2.4$ \\
\hline $\mathrm{K}(\mathrm{mmol} / \mathrm{L})$ & 5.23 & 4.93 & 5.04 & 5.05 & 0.09 & 0.667 & $3.4-6.1$ \\
\hline $\mathrm{Na}(\mathrm{mmol} / \mathrm{L})$ & 150.26 & 146.18 & 148.97 & 149.25 & 0.84 & 0.285 & $135-156$ \\
\hline $\mathrm{Mg}(\mathrm{mmol} / \mathrm{L})$ & 0.81 & 0.88 & 0.89 & 0.94 & 0.02 & 0.30 & $0.8-1.3$ \\
\hline $\mathrm{Cl}(\mathrm{mmol} / \mathrm{L})$ & 110.57 & 110.38 & 108.97 & 109.00 & 0.53 & 0.46 & $98-110$ \\
\hline $\mathrm{Fe}(\mu \mathrm{mol} / \mathrm{L})$ & $25.78^{\mathrm{a}}$ & $21.00^{\mathrm{a}}$ & $14.87^{\mathrm{b}}$ & $15.33^{\mathrm{b}}$ & 1.36 & 0.007 & $11.6-38.1^{1}$ \\
\hline
\end{tabular}

*Jackson and Cockcroft (2002); ${ }^{1}$ Kaneko et al. (2008); ${ }^{\text {a,b }}$ - values in rows with different letters differ significantly $(\mathrm{P}<0.05)$

Table 3. Blood biochemical parameters in Istrian goats of different ages

\begin{tabular}{|l|c|c|c|c|c|c|c|}
\hline Indicators & $\begin{array}{c}\text { Kids } \\
(\leq 6 \text { months })\end{array}$ & $\begin{array}{c}\text { Young goats } \\
(<2 \text { years })\end{array}$ & $\begin{array}{c}\text { Mature goats } \\
(2-5 \text { years })\end{array}$ & $\begin{array}{c}\text { Old goats } \\
(>5 \text { years })\end{array}$ & SEM & P-value & $\begin{array}{c}\text { Reference } \\
\text { values* }^{*}\end{array}$ \\
\hline Urea $(\mathrm{mmol} / \mathrm{L})$ & $4.89^{\mathrm{a}}$ & $4.49^{\mathrm{a}}$ & $7.40^{\mathrm{b}}$ & $7.36^{\mathrm{b}}$ & 0.49 & 0.04 & $4.0-8.6$ \\
\hline Protein $(\mathrm{g} / \mathrm{L})$ & $54.07^{\mathrm{a}}$ & $66.73^{\mathrm{b}}$ & $69.18^{\mathrm{b}}$ & $66.53^{\mathrm{b}}$ & 1.72 & 0.001 & $62-79$ \\
\hline Albumin $(\mathrm{g} / \mathrm{L})$ & 27.51 & 28.46 & 28.45 & 26.78 & 0.51 & 0.69 & $29-43$ \\
\hline Globulin $(\mathrm{g} / \mathrm{L})$ & $26.56^{\mathrm{a}}$ & $38.26^{\mathrm{b}}$ & $40.68^{\mathrm{b}}$ & $39.75^{\mathrm{b}}$ & 1.52 & 0.0001 & $35-57^{1}$ \\
\hline A/G & $1.07^{\mathrm{a}}$ & $0.75^{\mathrm{b}}$ & $0.71^{\mathrm{b}}$ & $0.68^{\mathrm{b}}$ & 0.04 & 0.0004 & - \\
\hline Glucose $(\mathrm{mmol} / \mathrm{L})$ & 3.97 & 2.83 & 3.16 & 3.02 & 0.20 & 0.17 & $2.4-4.0$ \\
\hline CHOL $(\mathrm{mmol} / \mathrm{L})$ & $2.84^{\mathrm{a}}$ & 2.16 & 2.16 & $1.76^{\mathrm{b}}$ & 0.13 & 0.03 & $1-3$ \\
\hline HDL $(\mathrm{mmol} / \mathrm{L})$ & 1.40 & 1.37 & 1.22 & 1.20 & 0.08 & 0.78 & $1.05-1.76^{2}$ \\
\hline LDL $(\mathrm{mmol} / \mathrm{L})$ & $0.99^{\mathrm{a}}$ & 0.59 & 0.56 & $0.39^{\mathrm{b}}$ & 0.06 & 0.01 & $0.77-1.25$ \\
\hline VLDL $(\mathrm{mmol} / \mathrm{L})$ & $0.17^{\mathrm{a}}$ & $0.09^{\mathrm{b}}$ & $0.07^{\mathrm{b}}$ & $0.07^{\mathrm{b}}$ & 0.01 & 0.0001 & - \\
\hline TG $(\mathrm{mmol} / \mathrm{L})$ & $0.84^{\mathrm{a}}$ & $0.44^{\mathrm{b}}$ & $0.37^{\mathrm{b}}$ & $0.38^{\mathrm{b}}$ & 0.05 & 0.0007 & 0.2 \\
\hline NEFA $(\mathrm{mmol} / \mathrm{L})$ & 0.05 & 0.03 & 0.04 & 0.06 & 0.006 & 0.39 & $<0.2^{2}$ \\
\hline BHB $(\mathrm{mmol} / \mathrm{L})$ & 0.21 & 0.36 & 0.43 & 0.37 & 0.04 & 0.07 & $0-1.2$ \\
\hline
\end{tabular}

*Jackson and Cockcroft (2002); ${ }^{1}$ Kaneko et al. (2008); ${ }^{2}$ Antunović et al. (2017a); ${ }^{\text {a,b }}$ - values in rows with different letters differ significantly $(\mathrm{P}<0.05)$; A/G - albumin/globulin, $\mathrm{CHOL}$ - cholesterol, HDL - high - density lipoprotein, LDL - low density lipoprotein, VLDL - very low - density lipoprotein cholesterol, TG - triglycerides, NEFA - non-esterified fatty acids, BHB - $\beta$-hydroxybutyrate. 
Z. Antunović et al.: Blood metabolic profile and acid-base status of Istrian goats

Table 4. Blood enzyme activities in Istrian goats of different ages (U/L)

\begin{tabular}{|l|c|c|c|c|c|c|c|}
\hline Enzymes & $\begin{array}{c}\text { Kids } \\
(\leq 6 \text { months })\end{array}$ & $\begin{array}{c}\text { Young goats } \\
(<2 \text { years })\end{array}$ & $\begin{array}{c}\text { Mature } \\
\text { goats } \\
(2-5 \text { years })\end{array}$ & $\begin{array}{c}\text { Old goats } \\
(>5 \text { years })\end{array}$ & SEM & P-value & $\begin{array}{c}\text { Reference } \\
\text { values* }\end{array}$ \\
\hline AST & $71.40^{\mathrm{a}}$ & 88.39 & $106.89^{\mathrm{b}}$ & 79.07 & 4.04 & 0.006 & $46-161$ \\
\hline ALT & 17.84 & 25.89 & 22.70 & 21.20 & 1.26 & 0.09 & $14-32^{1}$ \\
\hline GGT & 39.51 & 41.41 & 48.07 & 36.18 & 1.75 & 0.72 & $34-65$ \\
\hline CK & 163.71 & 153.00 & 201.83 & 192.75 & 16.81 & 0.17 & $119-200^{4}$ \\
\hline ALP & $568.99^{\mathrm{a}}$ & $254.62^{\mathrm{b}}$ & $244.50^{\mathrm{b}}$ & $242.78^{\mathrm{b}}$ & 43.13 & 0.006 & $200-255^{4}$ \\
\hline SOD & 0.35 & 0.37 & 0.30 & 0.54 & 0.04 & 0.17 & $0.184^{2}$ \\
\hline GPx & 1185.42 & 1174.59 & 1144.83 & 1360.68 & 70.98 & 0.82 & $>600^{3}$ \\
\hline
\end{tabular}

*Smith (2002); ${ }^{1}$ Tschuor et al. (2008.); ${ }^{2}$ Maan et al. (2013); ${ }^{3}$ Pavlata et al. (2012); ${ }^{4}$ Antunović et al. (2017a); a,b - values in rows with different letters differ significantly $(\mathrm{P}<0.05)$; AST - aspartate aminotransferase, ALT - alanine aminotransferase, GGT- $\gamma$ - glutamyl transferase, CK - creatine kinase, ALP - alkaline phosphatase, SOD - superoxide dismutase, GPx - glutathione peroxidase.

Table 5. Blood acid-base balance in Istrian goats of different ages

\begin{tabular}{|c|c|c|c|c|c|c|}
\hline & $\begin{array}{c}\text { Kids } \\
(\leq 6 \text { months })\end{array}$ & $\begin{array}{l}\text { Young goats } \\
\text { (<2 years) }\end{array}$ & $\begin{array}{l}\text { Mature goats } \\
(2-5 \text { years })\end{array}$ & $\begin{array}{l}\text { Old goats } \\
\text { (>5 years) }\end{array}$ & SEM & P-value \\
\hline $\mathrm{pH}$ & 7.29 & 7.31 & 7.35 & 7.32 & 0.05 & 0.27 \\
\hline $\mathrm{pCO}_{2}(\mathrm{kPa})$ & 7.4 & 7.18 & 6.83 & 6.78 & 0.22 & 0.82 \\
\hline $\mathrm{pO}_{2}(\mathrm{kPa})$ & 7.9 & 8.46 & 8.61 & 6.28 & 0.42 & 0.32 \\
\hline $\mathrm{HCO}_{3}(\mathrm{mmol} / \mathrm{L})$ & 25.83 & 26.25 & 27.41 & 26.13 & 0.48 & 0.68 \\
\hline $\mathrm{ctCO}_{2}(\mathrm{mmol} / \mathrm{L})$ & 27.51 & 27.94 & 28.97 & 27.70 & 0.51 & 0.76 \\
\hline Cbase(B) (mmol/L) & -0.70 & 0.24 & 1.37 & 0.13 & 0.49 & 0.25 \\
\hline Cbase(Ecf) (mmol/L) & 0.04 & 0.73 & 2.31 & 0.68 & 0.49 & 0.38 \\
\hline $\mathrm{sO}_{2}(\%)$ & 81.93 & 82.01 & 83.44 & 74.08 & 2.44 & 0.68 \\
\hline $\mathrm{SID}(\mathrm{mmol} / \mathrm{L})$ & 44.92 & 43.02 & 45.51 & 45.30 & 0.98 & 0.803 \\
\hline $\mathrm{AG}(\mathrm{mmol} / \mathrm{L})$ & 19.09 & 16.28 & 18.34 & 19.18 & 0.70 & 0.419 \\
\hline$z$ values & 0.30 & 0.29 & 0.31 & 0.30 & 0.005 & 0.812 \\
\hline$A T O T_{t \mathrm{p}}(\mathrm{mmol} / \mathrm{L})$ & $18.55^{\mathrm{b}}$ & $22.37^{\mathrm{a}}$ & $23.71^{\mathrm{a}}$ & $22.82^{\mathrm{a}}$ & 0.58 & 0.001 \\
\hline$A T O T_{a l b}(\mathrm{mmol} / \mathrm{L})$ & 17.11 & 17.43 & 17.70 & 16.65 & 0.32 & 0.774 \\
\hline $\mathrm{SIG}_{\mathrm{alb}}(\mathrm{mmol} / \mathrm{L})$ & -1.01 & -1.36 & -1.07 & -0.98 & 0.08 & 0.327 \\
\hline $\mathrm{SIG}_{\mathrm{tp}}(\mathrm{mmol} / \mathrm{L})$ & -1.09 & -1.74 & -1.43 & -1.36 & 0.11 & 0.144 \\
\hline $\mathrm{XA}(\mathrm{mmol} / \mathrm{L})$ & 5.91 & 3.99 & 5.95 & 7.22 & 0.92 & 0.712 \\
\hline
\end{tabular}

SEM- standard error of mean; ${ }^{a, b}$ - values in rows with different letters differ significantly $(\mathrm{P}<0.05)$; SID - strong ion difference, AG - anion gap, $A T O T_{\text {tp }}$ - weak anions and cations based on total protein calculations, $A T O T_{\text {alb }}$ - weak anions and cations based on albumin calculations, $\mathrm{SIG}_{\mathrm{alb}}$ - strong ion gap based on the serum concentrations of albumin, $\mathrm{SIG}_{\mathrm{tp}}$ - strong ion gap based on the serum concentrations of total protein, XA - unmeasured anions. 
in Turkey. In their study on Messinese goats, ARFUSO et al. (2016) determined higher RBC and a higher content of HGB in younger goats compared with older ones. BANERJEE et al. (2015) determined a lower content of haemoglobin in goats' blood in India during the summer compared to the winter season. Similar results regarding RBC and HGB content in some goat breeds in Italy were reported by PICCIONE et al. (2010), while EGBE-NWIYI et al. (2000) determined the same in goats in Nigeria. Changes in RBC could be related to the oxygen carrying capacity of the blood, which is higher in young goats than in old ones (DARAMOLA et al., 2005). In young calves, $\mathrm{RBC}$ might be higher, and $\mathrm{MCV}$ and $\mathrm{MCHC}$ might be lower than in adults (JONES and ALLISON, 2007). With the rise in environmental temperature, animals lose liquid through their respiratory tract, reducing the blood plasma volume and increasing the haematocrit concentration. If physiological excretion is prolonged, dehydration occurs and thus, loss of fluids by the evaporation process results in increased haematocrit (RIBEIRO et al., 2018). The higher values of MCV in the blood of Istrian goats compared to the reference values could be related to the high air temperatures during blood sampling, which is in accordance with the study by AENGWANICH (2007) that determined higher MCV in broilers under heat stress. Research has shown that blood MVC content could be used in haematological analysis of the response of cattle to thermal and humidity stress (AENGWANICH et al., 2009). In adult animals, the lymphocyte content decreases progressively but remains the dominant cell type (ROLAND et al., 2014). The content value for neutrophils was higher for adult Borno white goats than for the kids of this breed (NJIDDA et al., 2013). Lymphocytes are the dominant WBC in young ruminants, but with increased age, the distribution of lymphocytes and neutrophils is equal. Goats have an equal or slightly increased neutrophil percentage when compared to lymphocytes (JONES, 2011). In cattle blood, the eosinophil percentage increases with age (WOOD and QUIROZ-ROCHA, 2010). In sheep, age caused an increase in neutrophil and eosinophil counts in the research by EGBE-NWIYI et al. (2000) in Nigeria. However, an increased eosinophil percentage in blood may be a result of parasite migration (JONES, 2011).

In the current study, significant decreases in $\mathrm{Fe}, \mathrm{A} / \mathrm{G}$ ratio, cholesterol, triglycerides, VLDLand LDL-cholesterol, $\mathrm{P}$ and activities of ALP were determined, as well as significant increase in urea, total protein and globulin concentrations with the age of the goats. A significant increase in AST and content of $A T O T_{t p}$ in the blood of the goats was determined with age. The reference values for urea in goats $(4.0-8.6 \mathrm{mmol} / \mathrm{L})$ that, according to JACKSON and COCKCROFT (2002) were determined in the present study (average values from 4.49 to $7.60 \mathrm{mmol} / \mathrm{L}$ ), may be related to the adequate content of proteins in the goats' diet. KOHN et al. (2005) determined that the concentration of urea may be considered as a good indicator of the amount of nitrogen consumed in feed. Many reports have suggested that urea concentration is lower in young ruminants than in adult ruminants (NJIDDA et al., 2014). In the present study, a significant increase in total protein concentrations with age was determined in the goats ( $\leq 6$ months to 5 years), and a significant decrease in goats older than 5 years. Furthermore, in their research, carried out in Thailand, RATTANA et al. (2011) also determined an increased concentration of total proteins and globulins in the serum of goats $(6.17-6.63 \mathrm{~g} / \mathrm{dL}$ and $2.79-3.55 \mathrm{~g} / \mathrm{dL})$ with age, (0-6 months to $>2$ years). PICCIONE et al. (2010) reported a significant increase in the relative amount $\gamma$-globulins associated with a significant decrease in the $\mathrm{A} / \mathrm{G}$ ratio in adult Girgentana goats. With increased age, blood proteins seem to increase, which is shown in the decrease in albumin concentration and in the progressive increase in the globulin fraction (KANEKO et al., 2008). DEANGELINO et al. (1990) determined a significantly lower total protein concentration in young goats when compared to adult goats. In this study, the average concentration of albumin in the blood of goats $(26.78-28.46 \mathrm{~g} / \mathrm{L})$ was below the reference range for goats according to JACKSON and COCKCROFT (2002; 29.43-43 g/L). The plasma $\mathrm{Ca}$ levels in goats younger than 1 year were below the reference values (JACKSON and COCKCROFT, 2002; 2.3-2.9 mmol/L). KANEKO 
et al. (2008) reported that serum phosphate might be higher in younger animals because the growth hormone increased renal phosphate resorption. Higher concentrations of $\mathrm{Fe}$ in the blood of the youngest goats could be due to the rapid metabolic processes related to the increase in their body weight (ANTUNOVIĆ et al., 2004).

KIRAN et al. (2012) determined a similar trend for blood cholesterol concentration in goats from Pakistan, although without significant differences between different age groups of goats. On the contrary, KARAŞAHIN et al. (2018) determined the opposite trend in cholesterol concentrations in female Hair goats in Turkey. In the research by NAZIFI et al. (2002) conducted on Iranian male goats, the significant effect of age was determined on the concentrations of triglycerides and VLDLcholesterol in serum, with values being lower in older animals. Higher cholesterol concentrations during a growth period are responsible for building cholesterol reserve for steroidogenesis of various steroid gonadal hormones during the prepubertal and pubertal periods (GATTANI and SAREEN, 2011). Furthermore, a decreased cholesterol concentration with high ambient temperature might be due to the decrease in acetate concentration, which is the primary precursor for cholesterol synthesis(O'CAK et al., 2009). CARLOS et al. (2015) determined a significant decrease in triglyceride concentration with age in the blood of Morada Nova sheep.

The energy status of goats can be assessed by determination of glucose and NEFA concentrations in their blood (FERNANDEZ et al., 2007). When analysing these parameters in Istrian goats, no glucose deficit was determined. Concentrations of BHB were also within the reference values, with no evidence of metabolic disease. DORÉ et al. (2015) reported that hypokeratonaemia definition is based on a BHB concentration between $\geq 0.4$ and $\geq 0.9$ $\mathrm{mmol} / \mathrm{L}$.

Serum AST levels were higher in adult goats than in the youngest group. The higher activities of AST in the blood of older goats may be used as an indicator of physical stress (MBASSA and POULSEN, 1991). An increase in AST activities in the blood of Girgentana goats was determined by PICCIONE et al. (2010) and by NJIDDA et al. (2014) in different breeds of sheep in Nigeria. In the present research, the activity of ALP was significantly higher in goat kids than in older goats. High levels of this enzyme were correlated with high osteoblastic activity in young animals (DURAK et al., 2015). Similar results were obtained by ELITOK (2012) in Turkey. HASER and FÜRLL (2015) determined GPx activity that increased continuously from the age of day 1 to the $6^{\text {th }}$ month. SOD activity at days 1 and 7 was lower than on day 1 and at the age of 3 months. Activities at 12 and 18 months were lower compared to the ages of 1 , 3 and 6 months. The authors concluded that these results displayed the functioning of the antioxidant defence system in the calf during growth. In the present study, the activities of SOD and GPx were similar in kids and older goats.

In general, metabolic activity modifies the acidbase balance, although it is difficult to estimate the degree of its contribution to the metabolic component of the acid-base balance (CASTILLO et al., 2000). In this study, no changes were determined in the parameters of the acid-base status, except for the values of $A T O T_{t p}$ which could be related to changes in the concentrations of total proteins in the blood of goats with age.

\section{Conclusion}

These results of tests of the metabolic profile and acid-base status of Istrian goats are the first published physiological values that may be useful for understanding the Istrian goat metabolism. Therefore, this will help to monitor the health and nutritional status, and to improve the management and conservation of this critically endangered breed. The findings that the blood content of $\mathrm{MCHC}$ and concentration of $\mathrm{Ca}$ and albumins were below, and triglycerides and MCV were above the reference intervals might indicate that the reference values used were inappropriate for the Istrian goat breed.

\section{Conflicts of interest}

The authors declare that they have no conflict of interest. 


\section{References}

AENGWANICH, W. (2007): Effects of high environmental temperature on blood indices of thai indigenous chickens, thai indigenous chickens crossbred and broilers. Int. J. Poultry Sci. 6, 427-430.

DOI: $10.3923 /$ ijps.2007.427.430

AENGWANICH, W., A. CHANTIRATIKUL, S. PAMOK (2009): Effect of seasonal variations on haematological values and health monitor of crossbred beef cattle at slaughterhouse in northeastern part of Thailand. Am. Eurasian J. Agr. Environ. Sci. (JAES) 5, 644-648.

ANTUNOVIĆ, Z., M. ŠPERANDA, Z. STEINER (2004): The influence of age and the reproductive status to the blood indicators of ewes. Arch. Tierz. Dummerstorf. 47, 265-273. DOI: $10.5194 / \mathrm{aab}-47-265-2004$

ANTUNOVIĆ, Z., J. NOVOSELEC, Ž. KLIR, M. ĐIDARA (2013): Hematological parameters in the Alpine goats during lactation. Poljoprivreda/Agriculture 19, 40-43.

ANTUNOVIĆ, Z., M. ŠPERANDA, J. NOVOSELEC, M. ĐIDARA, B. MIOČ, Ž. KLIR, D. SAMAC (2017a): Blood metabolic profile and acid-base balance of dairy goats and their kids during lactation. Vet. arhiv 87, 43-55.

ANTUNOVIĆ, Z., J. NOVOSELEC, Ž. KLIR (2017b): Hematological parameters in ewes during lactation in organic farming. Poljoprivreda/Agriculture. 23, 46-52.

ANTUNOVIĆ, Z., K. NOVAKOVIĆ, Ž. KLIR, J. NOVOSELEC (2019): Phenotypic characteristics of different age categories of Istrian goat. Proceedings of the $54^{\text {th }}$ Croatian $\& 14^{\text {th }}$ International Symposium on Agriculture, 17-22 February, Vodice, Croatia, pp. 429-433.

ARFUSO, F., F. FAZIO, M. RIZZO, S. MARAFIOTI, E. ZANGHI, G. PICCIONE (2016): Factors affecting the haematological parameters in different goat breeds from Italy. Ann. Anim. Sci. 16, 743-757.

DOI: $10.1515 /$ aoas-2015-0094

BANERJEE, D., R. C. UPADHYAY, U. B. CHAUDHARY, R. KUMAR, S. SINGH, ASHUTOSH, T. K. DAS, S. DE. (2015): Seasonal variations in physio-biochemical profiles of Indian goats in the paradigm of hot and cold climate. Biol. Rhythm Res. 46, 221-236.

DOI: 10.1080/09291016.2014.984999

CABIDDU, A., A. BRANCA, M. DECANDIA, A. PES, P. M. SANTUCCI, F. MASOERO, L. CALAMARI (1999): Relationship between body condition score, metabolic profile, milk yield and milk composition in goats browsing a Mediterranean shrubland. Livest. Prod. Sci. 61, 267-273. DOI: 10.1016/S0301-6226(99)00076-7

CAA (2019): Croatian Agricultural Agency, Annual report. Sheep, goats and small animals breeding. Ministry of Agriculture, Zagreb, Croatia, p. 143.

CARlos, M. M. L., LEITE, J. H. G. M., CHAVES, D. F., VALE, A. M., FACANHA, D. A. E., MELO, M. M., SOTOBLANCO B. (2015): Blood parameters in the Morada
Nova sheep: influence of age, sex and body condition score. J. Anim. Plant Sci. 25, 950-955.

CASTILlO, C., J. HERNANDEZ, J. L. BENEDITO, M. LOPEZ-ALONSO, M. MIRANDA, C. GUTIERREZPANIZO, J. SOTILLO (2000): Quantitative evaluation of acid-base balance on milk producing goats: Effect of sex and milk yield. Vet. Med.-Czech. 45, 241-246.

CONSTABLE, P. D. (1999): Clinical assessment of acid-base status. Strong ion difference theory. Vet. Clin. North A. Food Anim. Pract. 15, 447-471.

DOI: $10.1016 / \mathrm{S} 0749-0720(15) 30158-4$

CONSTABLE, P. D. (2002): Calculation of variables describing plasma non-volatile weak acids for use in the strong ion approach to acid-base balance in cattle. Am. J. Vet. Res. 63, 482-90.

DOI: $10.2460 /$ ajvr.2002.63.482

DARAMOLA, J., A. ADELOYE, T. FATOBA, A. SOLADOYE (2005): Haematological and biochemical parameters of West African Dwarf goats. Livest. Res. Rural Dev. 17, 7-8.

DEANGELINO, J. L., M. M. ISHIZUKA, L. RIBEIRO, T. V. TUCCI, E. H. BIRGEL (1990): Standard serum biochemical values of healthy goats reared in Saopaulo state. Braz. Vet. Res. Anim. Sci. 27, 91-97.

DORÉ, V., J. DUBUC, A. M. BÉLANGER, S. BUZZINSKI (2015): Definition of prepartum hypoketonemia in dairy goats. J. Dairy Sci. 98, 4535-4543.

DOI: $10.3168 /$ jds.2014-9172

DURAK, M. H., R. E. C. ERKAN, R. ÇELIK, B. YOKUŞ, D. KURT, S. GÜRGÖZE (2015): The effects of age and gender on some biochemical serum parameters in Zom sheep raised in the vinicity Karacadağ. Isr. J. Vet. Med. 70, 33-39.

EGBE-NWIYI, T. N., S. C. NWAOSU, H. A. SALAMI (2000): Haematological values of apparently healthy sheep and goats as influenced by age and sex in arid zone of Nigeria. Afr. J. Biomed. Res. 3, 109-115.

ELITOK, B. (2012): Reference values for haematological and biochemical parameters in saanen goats breeding in Afyonkarahisar province. Kocatepe Vet. J. 5, 7-11.

FAO (2015): The second report on the state of the World's animal genetic resources for food and agriculture. FAO Commision on genetic resources for food and agriculture assessments. Rome, http://www.fao.org/3/a-i4787e/index. html

FERNANDEZ, J. R., E. RAMOS, G. DE LA TORE, R. HERMOSO, F.G. EXTREMERA, M. R. SANZ SAMPELAYO (2007): Blood metabolites as indicators of energy status in goats. Option Mediterraneennes, Seria A. 74, 451-455.

FRIEDEWALD, W.T., R.I. LEVY, D.S. FREDRICKSON (1972): Estimation of the concentration of low-density lipoprotein cholesterol in plasma, without use of the preparative ultracentrifuge. Clin. Chem. 18, 499-502. 
GATTANI, A., M. SAREEN (2011): Influence of age and season on thyroid activity and blood biochemical profile in Magra rams under arid tropical environment. Indian J. Small Ruminants. 17, 237-239.

GÄRTNER, T., V. ZOCHE-GOLOB, S. REDLBERGER, P. REINHOLD, K. DONAT (2019): Acid-base assessment of post-parturient German Holstein dairy cows from jugular venous blood and urine: A comparison of the strong ion approach and traditional blood gas analysis. PLOS one. 14, e0210948.

DOI: 10.1371/journal.pone.0210948

HASER D., M. FÜRLL (2015): Age-related changes in antioxidant parameters in healthy calves between the first day of life and the $18^{\text {th }}$ month taking into consideration selected metabolic parameters. Tierarztl. Prax. Ausg. G. 43, 5-13.

IVANKOVIĆ, A., B. MIOČ, G. ŠUBARA, P. DOVČ, I. ŠIRIĆ, J. RAMLJAK (2018). Genetic characterization of Istrian goat: the key-point for a long-term conservation. Mljekarstvo. 68, 85-97.

DOI: $10.15567 / \mathrm{mljekarstvo.2018.0202}$

JACKSON, P. G. G., P. D. COCKCROFT (2002): Clinical examination of farm animals. Blackwell Science Ltd., Oxford, UK, pp. 302-305.

JONES, M. L., R. W. ALLISON (2007): Evaluation of the ruminant complete blood cell count. Vet. Clin. Food Anim. 23, 377-402.

DOI: $10.1016 /$ j.cvfa.2007.07.002

JONES, M. (2011): Interpreting of blood work in small ruminants. Central Veterinary Conference (CVC). Kansas City, MO: DVM360.

KANEKO, J. J., J. W. HARVEY, M. L. BRUSS (2008): Clinical Biochemistry of Domestic Animals. $6^{\text {th }}$ ed., Elsevier, Academic Press, Amsterdam, Netherlands, p. 931.

KARAŞAHIN, T., N. H.AKSOY,A.E.HAYDARDEDEOĞLU, S. DURSUN, G. BULUT, G. ÇAMKERTEN, I. ÇAMKERTEN, R. İLGÜN (2018): Serum cholesterol levels in Hair goats of Aksaray Region. Indian J. Anim. Res. B, 878, 1-4.

DOI: 10.18805/ijar.B-878

KIRAN, S., A. M. BHUTTA, B.A. KHAN, S. DURRANI, M. ALI, M. ALI, F. IQBAL (2012): Effect of age and gender on some blood biochemical parameters of apparently healthy small ruminants from Southern Punjab in Pakistan. Asian Pac. J. Trop. Biomed. 2, 304-306.

DOI: 10.1016/S2221-1691(12)60028-8

KOHN, R. A., M. M. DINNEEN, E. RUSSEK-COHEN (2005): Using blood urea nitrogen to predict nitrogen excretion and efficiency of nitrogen utilization in cattle, sheep, goats, horses, pigs and rats. J. Anim. Sci. 83, 879-889.

DOI: $10.2527 / 2005.834879 \mathrm{x}$

KRAMER, J. W. (2000): Normal hematology of cattle, sheep and goats. In: Schalm's Veterinary Hematology. (Feldman,
B. F., J. G. Zinkl, N. C. Jain, Eds.), Lippincott Williams \& Wilkins, Philadelphia, USA, pp. 1075-1084.

MAAN, R., N. KATARIA, P. K. PILAMA, A. SHARMA, S. ARORA, A. JOSHI, L. N. SANKHALA, S. SHARMA, N. MOHAMMAD, P. NATHAWAT, A. KATARIA (2013): Superoxide dismutase profiling during extreme ambiences in Marwari sheep from arid tracts. Vet. Res. 6, 15-18.

DOI: $10.3923 / \mathrm{vr} .2013 .15 .18$

MBASSA, G. K., J. S. POULSEN (1991): Influence of pregnancy, lactation and environment on some clinical reference values in Danish Landrace dairy goats (Capra Hircus) of different parity-I. Electrolytes and enzymes. Comp. Biochem. Physiol. 100B, 413-422.

DOI: 10.1016/0305-0491(91)90395-T

MIOČ, B., A. IVANKOVIĆ, I. ŠIRIĆ, V. DRŽAIĆ (2013): Exterior characteristics of Istrian goat. Proceedings of the $48^{\text {th }}$ Croatian $\& 8^{\text {th }}$ International Symposium on Agriculture, 17-22 February, Dubrovnik, Croatia, pp. 765-769.

MOHAMMED, S. A., M. A. RAZZAQUE, A.E. OMAR, S. ALBERT, W. M. AL-GALLAF (2016): Biochemical and hematological profile of different breeds of goat maintained under intensive production system. Afr. J. Biotechnol. 15, 1253-1257.

DOI: $10.5897 / A J B 2016.15362$

NAZIFI, S., H. R. GHEISARI, F. SHAKER (2002): Serum lipids and lipoprioteins and their correlations with thyroid hormone sin clinically health goats. Vet. arhiv 72, 249-257.

NJIDDA, A. A., I. T. HASSAN, E. A. OLATUNJI (2013): Haematological and biochemical parameters of goat of semi arid environment fed on natural grazing rangeland of northern Nigeria. ISOR J. Agr. Vet. Sci. 3, 1-8.

DOI: $10.9790 / 2380-0320108$

NJIDDA, A. A., A. A. SHUAI'BU, C. E. ISIDAHOMEN (2014): Haematological and serum biochemical indices of sheep in semi-arid environment of northern Nigeria. Global J. Sci. Front. Res. Agr. Vet. 14, I.

O'CAK, S., N. DARCAN, S. CANKAYA, C. T. INAL (2009): Physiological and biochemical responses in German Fawn kids subjected to cooling treatments under Mediterranean climate conditions. Turk. J. Vet. Anim. Sci. 33, 455-461. DOI: $10.3906 /$ vet-0708-3

OTTER, A. (2013): Diagnostic blood biochemistry and haematology in cattle. In Practice 35, 7-16.

DOI: 10.1136/inp.e8719

PAVLATA, L., L. MISUROVA, A. PECHOVA, T. HUSAKOVA, R. DVORAK (2012.): Direct and indirect assessment of selenium status in sheep-a comparison. Vet. Med. 57, 219-223.

DOI: 10.17221/5951-VETMED

PICCIONE, G., S. CASELLA, L. LUTRI, I. VAZZANA, V. FERRANTELLI, G. CAOLA (2010): Reference values for some haematological, haematochemical, and 
electrophoretic parameters in the Girgentana goat. Turk. J. Vet. Anim. Sci. 34, 197-204.

DOI: $10.3906 /$ vet-0902-1

PICCIONE, G., V. MONTEVERDE, M. RIZZO, I. VAZZANA, A. ASSENZA, A. ZUMBO, P. P. NIUTTA (2014): Reference intervals of some electrophoretic and haematological parameters in Italian goats: comparison between Girgentana and Aspromontana breeds. J. Appl. Anim. Res. 42, 434-439.

DOI: $10.1080 / 09712119.2013 .875914$

RADIN, L., A. SHEK VUGROVEČKI, J. PEJAKOVIĆ HLEDE, S. VINCE, I. LJUBIČIĆ, M. ŠIMPRAGA (2017): Blood metabolites of extensively reared Croatian multicoloured goats during early lactation and early gravidity. Vet. arhiv 87, 273-280.

DOI: $10.24099 /$ vet.arhiv. 151223

RATTANA, S., O. ARUNSAKUL, P. SANGKHAPAITOON (2011): Biochemical blood parameters of goat in southern Thailand. J. Agr. Res. Int. Relat. 27, 283-292.

REDLBERGER, S., S. FISHER, H. KÖHLER, R. DILLER, P. REINHOLD (2017): Age-dependent physiological dynamics in acid-base balance, electrolytes, and blood metabolites in growing goats. Vet. J. 229, 45-52.

DOI: $10.1016 /$ j.tvj1.2017.10.017

RIBEIRO, M. N., N. L. RIBEIRO, R. BOZZI, R. G. COSTA (2018): Physiological and biochemical blood variables of goats subjected to heat stress-a review. J. Appl. Anim. Res. 46, 1036-1041.

DOI: $10.1080 / 09712119.2018 .1456439$

ROLAND, L., M. DRILLICH, M. IWERSEN (2014): Hematology as a diagnostic tool in bovine medicine. J. Vet. Diagn. Invest. 26, 592-598.

DOI: $10.1177 / 1040638714546490$
SMITH, B. P. (2002.): Large Animal Internal Medicine. Copyright Mosby, Inc., p. 393.

STEWART, P. A. (1983): Modern quantitative acid-base chemistry. Can. J. Physiol. Pharm. 61, 1441-1461.

DOI: $10.1139 / \mathrm{y} 83-207$

TSCHUOR, A. C., RIOND, B., BRAUN, U., LUTZ, H. (2008): Hämatologische und klinisch-chemische Referenzwerte für adulte Ziegen und Schafe. Schweiz. Arch. Tierheilk. $150,287-295$.

DOI: $10.5167 /$ uzh-9904

SAS 9.4 ${ }^{\circledR}$ (2002-2012) SAS Institute Inc., Cary, NC, USA

VAN SAUN, R. (2000): Blood profile as indicators of nutritional status. Department of Large Animal Clinical Sciences. College of Veterinary medicine. Oregon State University, Corvallis, Oregon, USA, pp. 97331-94802.

WALLER, A., M. I. LINDINGER (2005): Physiochemical analysis of acid-base status during recovery from highintensity exercise in Standardbred racehorses. Equine Comp. Exerc. Physiol. 2, 119-127.

DOI: $10.1079 / \mathrm{ECP} 200549$

WHITEHAIR, K. A., S. C. HASKINS, J. G. WHITEHAIR, P. J. PASCOE (1995): Clinical applications of quantitative acid-base chemistry. J. Vet. Intern. Med. 9, 1-11.

DOI: $10.1111 / j .1939-1676.1995 . t b 03265 . x$

WOOD, D., G. F. QUIROZ-ROCHA (2010): Normal hematology of cattle. In: Schalm's veterinary hematology (Weiss, D. J., K. J. Wardrop, Eds.) Wiley, Ames, IA, pp. 829-835.

\section{ANTUNOVIĆ, Z., K. NOVAKOVIĆ, Ž. KLIR, V. ŠERIĆ, B. MIOČ, M. ŠPERANDA, M. RONTA, J. NOVOSELEC: Utjecaj dobi na metabolički profil krvi i acido-bazni status istarske koze - kritično ugrožene hrvatske pasmine. Vet. arhiv 90, 27-38, 2020. \\ SAŽETAK}

Cilj istraživanja bio je utvrditi metabolički profil krvi i acido-bazni status istarskih koza u mediteranskom sustavu proizvodnje. Istraživanje je provedeno na 28 istarskih koza, podijeljenih u četiri skupine: skupina I - jarad dobi do 6 mjeseci; skupina II - koze dobi do 2 godine; skupina 3 - koze dobi od 2 do 5 godina; skupina IV - koze starije od 5 godina. Koze su napasivale ekstenzivne, mediteranske pašnjake, a nakon povratka u staju hranjene su sijenom i s približno $0,2 \mathrm{~kg} / \mathrm{dan}$ kukuruza, uz vodu i sol koja im je bila na raspolaganju po volji. Hematološki pokazatelji i diferencijalna krva slika određeni su u punoj krvi koza. Koncentracija biokemijskih pokazatelja te aktivnosti enzima određene su u krvnom serumu, dok su pokazatelji acido-baznog statusa određene u plazmi. Broj eritrocita te udio limfocita bio 
je smanjen, dok se udio segmentiranih neutrofila i eozinofila povećao s dobi istarskih koza. Utvrđeno je znakovito smanjenje koncentracije Fe, omjera albumina i globulina, koncentracije kolesterola, triglicerida, LDL-kolesterola, VLDL-kolesterola, anorganskog fosfora te aktivnosti alkalne fosfataze. Suprotno je utvrđeno u koncentracijama ureje, ukupnih proteina i globulina, kao i aktivnosti aspartat-aminostransferaze te aniona i kationa temeljenih na izračunu iz ukupnih proteina. Dobiveni rezultati o metaboličkom profilu i acido-baznom statusu istarskih koza prve su objavljene referentne vrijednosti koje će pomoći u praćenju zdravstvenog i nutritivnog statusa te u poboljšanju upravljanja $\mathrm{i}$ očuvanja ove kritično ugrožene pasmine.

Ključne riječi: metabolički profil; acido-bazni status; mediteranski sustav proizvodnje; istarska koza 